\title{
MODEL PEMBELAJARAN DISCOVERY LEARNING UNTUK MENINGKATKAN HASIL BELAJAR MEMBACA PEMAHAMAN TEKS REPORT SISWA KELAS 9A SEMESTER GENAP SMPN 17 JAKARTA TAHUN 2019/2020
}

\author{
MUH. HERMANTO \\ Guru SMP Negeri 17 Jakarta \\ e-mail: muh.hermanto70@gmail.com
}

\begin{abstract}
ABSTRAK
Penelitian tindakan kelas ini dilatarbelakangi oleh rendahnya hasil belajar siswa materi membaca pemahaman teks report, minat baca yang rendah, aktivitas membaca teks berbahasa Inggris kurang, dan kurangnya motivasi siswa untuk membaca teks berbahasa Inggris, serta metode pembelajaran yang diterapkan guru kurang menarik.. Tujuan dilakukan penelitian tindakan kelas yaitu untuk meningkatkan hasil belajar membaca pemahaman teks report dan untuk meningkatkan aktivitas pembelajaran bahasa Inggris bagi siswa kelas 9A SMPN 17 Jakarta. Penelitian dilaksanakan di kelas 9A SMPN 17 Jakarta selama satu bulan yaitu mulai 8 Februari 2020 sampai dengan tanggal 21 Maret 2020. Subjek penelitian kelas 9A yang berjumlah 35 orang. Metode yang digunakan penelitian tindakan kelas (classroom action research) yang terdiri dari dua siklus. Tiap siklus terdiri dari empat tahap, yakni: 1) perencanaan; 2) pelaksanaan; 3) observasi; dan 4) refleksi. Hasil dari penelitian disimpulkan 1)Penerapan model pembelajaran discovery learning ternyata mampu meningkatkan hasil belajar membaca pemahaman teks report. Hal ini dapat diketahui dari adanya peningkatan jumlah siswa yang mengalami ketuntasan belajar dari siklus 1 hingga siklus II. Hal ini dapat dibuktikan dengan hasil belajar membaca pemahaman teks report menggunakan model discovery Learning. Nilai rata-rata hasil belajar membaca pemahaman teks report pada pra siklus adalah 73,94 meningkat menjadi 77,29 pada siklus I dan 83,71 pada siklus II. Jumlah siswa tuntas pada pra siklus ada 48,6\%, meningkat menjadi $71,4 \%$ pada siklus I dan meningkat lagi sebesar 91,4\% pada siklus II. 2) Telah terjadi perubahan perilaku aktivitas belajar yang signifikan pada siswa. Hal ini ditunjukkan dengan adanya peningkatan keaktifan siswa pada siklus 1 siswa yang aktif $65,7 \%$, pada siklus II terjadi peningkatan, yakni mencapai 94,3\%.
\end{abstract}

Kata Kunci:: hasil belajar membaca pemahaman teks report, model pembelajaran discovery learning. 


\section{PENDAHULUAN}

Kemampuan membaca merupakan bekal dan kunci keberhasilan siswa dalam menjalani proses pendidikan. Sebagian besar pemerolehan ilmu dilakukan siswa melalui aktivitas membaca. Ilmu yang diperoleh siswa tidak hanya didapat dari proses belajar mengajar di sekolah, tetapi juga melalui kegiatan membaca dalam kehidupan sehari-hari. Oleh karena itu, kemampuan membaca dan kemampuan memahami bacaan menjadi bagian penting dalam keberhasilan siswa dalam mempelajari bahasa. Hakikat membaca adalah memperoleh makna yang tepat (Zuchdi, 2008:19). Membaca memerlukan konsentrasi yang lebih untuk memperoleh makna yang tepat.

Rendahnya semangat belajar siswa mempengaruhi daya pemahaman siswa dalam belajar. Fakta lain penyebab rendahnya hasil belajar membaca pemahaman teks report menurut observasi awal disebabkan oleh beberapa faktor yaitu: a)guru banyak menggunakan metode ceramah sehingga siswa tidak aktif dalam pembelajaran, b) guru kurang memberikan variasi dalam pembelajaran c) siswa kurang siap dalam menerima materi. Hal ini juga sesuai pendapat Soedarso (2010:32) bahwa "Membaca adalah aktivitas yang kompleks dengan mengerahkan sejumlah besar tindakan yang terpisah-pisah, meliputi orang harus menggunakan pengertian dan khayalan, mengamati, dan mengingat-ingat". Fakta menunjukkan bahwa prestasi hasil membaca pemahaman (reading comprehension) siswa kelas 9A masih rendah. Rendahnya pemahaman reading comprehension diketahui dari rata-rata nilai tugas dan ulangan harian membaca pemahaman (reading comprehension) hanya 73,94, di bawah nilai KKM 75, dengan ketuntasan 15 siswa atau 48,6\%, dan siswa yang belum tuntas ada $17(51,4 \%)$, dari jumlah keseluruhan 35 siswa pada kelas 9A.

\section{Hasil Belajar Membaca Pemahaman Teks Report Pra Siklus}

\begin{tabular}{|l|l|}
\hline Nilai Rata-rata & 73,94 \\
\hline Jumlah siswa yang tuntas & 17 \\
\hline Jumlah siswa yang tidak tuntas & 18 \\
\hline Prosentase ketuntasan belajar & $48,6 \%$ \\
\hline Nilai tertinggi & 94 \\
\hline Nilai terendah & 60 \\
\hline Tingkat keaktifan siswa & $45,7 \%$ \\
\hline
\end{tabular}

Dari tabel di atas, dapat diketahui kemampuan awal siswa dalam membaca pemahaman teks report dengan nilai rata-rata 73,94, nilai terendah 60 , nilai tertinggi 94 dengan jumlah siswa tuntas sebanyak 17 siswa atau 48,6\% dan jumlah siswa yang tidak tuntas 18 atau 51,4\%. Tingkat keaktifan siswa dalam proses pembelajaran sebanyak $45,7 \%$. Dari hasil pengamatan dan paparan hasil di atas dapat diambil kesimpulan:

a. Keaktifan siswa dalam mengikuti pembelajaran: 45,7\% atau hanya 16 siswa yang aktif dalam kegiatan belajar 
b. Nilai rata-rata kemampuan siswa membaca pemahaman teks report pada pra siklus sebesar 73,94 dengan ketuntasan klasikal sebesar 48,6\%.

Istilah report text sering juga dikenal dengan sebutan informational report. Report, dalam Concise Oxford Dictionary Edisi 10 (2010), diartikan sebagai 1) an account given of a matter after investigation or consideration. 2) a piece of information about an event or situation. Jika disimpulkan, secara bahasa report text adalah teks yang berfungsi untuk memberikan informasi tentang suatu peristiwa atau situasi, setelah diadakannya investigasi dan melalui berbagai pertimbangan

Ada beberapa faktor yang menyebabkan rendahnya hasil belajar membaca pemahaman (reading comprehension) Bahasa Inggris siswa kelas 9A yaitu minat baca yang rendah, aktivitas membaca teks berbahasa Inggris kurang, dan kurangnya motivasi siswa untuk membaca teks berbahasa Inggris, metode pembelajaran yang diterapkan guru kurang menarik. Hal ini harus segera dicarikan solusi agar kemampuan membaca pemahaman siswa meningkat. Solusi yang digunakan untuk mengatasi hal tersebut yaitu dengan menerapkan model pembelajaran discovery learning. Menurut Mulyono (2012:221) discovery learning menekankan kepada proses, mencari dan menemukan, materi pelajaran tidak diberikan secara langsung.

Pemilihan model pembelajaran discovery learning, ditentukan oleh beberapa pertimbangan berikut ini.

1. Karakteristik pengetahuan yang dikembangkan menurut kategori faktual,

2. Karakteristik keterampilan yang tertuang pada rumusan kompetensi dasar dari KI- 3 yaitu pada keterampilan menangkap makna, menyusun, dan menyunting teks.

3. Pemilihan model tersebut mempertimbangkan sikap yang dikembangkan, baik sikap religius (KI-1) maupun sikap sosial (KI-2).

Tujuan pembelajaran memahami bacaan berbahasa Inggris adalah agar siswa dapat menerima pesan yang disampaikan oleh si penulis sebagai pengirim pesan kepada penerima pesan. Pesan yang disampaikan penulis tercantum dalam berbagai bentuk teks fungsional pendek yang didalamnya terdapat pula nilai- nilai budaya. Pembaca yaitu siswa SMP diharapkan dapat pula menghubungkan keterkaitan antara bahasa dan nilai - nilai (budaya) yang terdapat dalam bacaan.

Agar tujuan tersebut tercapai maka para guru melaksanakan pembelajaran dengan menggunakan beberapa model pembelajaran diantaranya, model discovery learning.

\section{METODE PENELITIAN}

Metode penelitian ini adalah PTK (Penelitian Tindakan Kelas). Penelitian ini menggunakan 2 siklus yang setiap siklus terdiri dari satu kali pertemuan. Menurut Tim Pelatih Proyek PGSM PTK adalah suatu bentuk kajian yang bersifat reflektif oleh pelaku tindakan yang dilakukan untuk meningkatkan kemantapan rasional dari tindakan mereka dalam melaksanakan tugas, memperdalam pemahaman terhadap 
tindakan yang dilakukan itu, serta memperbaiki kondisi dimana praktik pembelajaran tersebut dilakukan. Menurut Arikunto (2012:17) satu siklus penelitian tindakan kelas memiliki empat tahap dasar yang saling terkait dan berkesinambungan, yaitu Planning (Rencana), Action (Tindakan), Observasi (pengamatan), Reflection (refleksi). Penelitian ini dirancang dalam 2 siklus.

Berikut ini adalah gambar rancangan penelitian tindakan kelas menurut Stephen Kemmis dan Mc. Taggart.

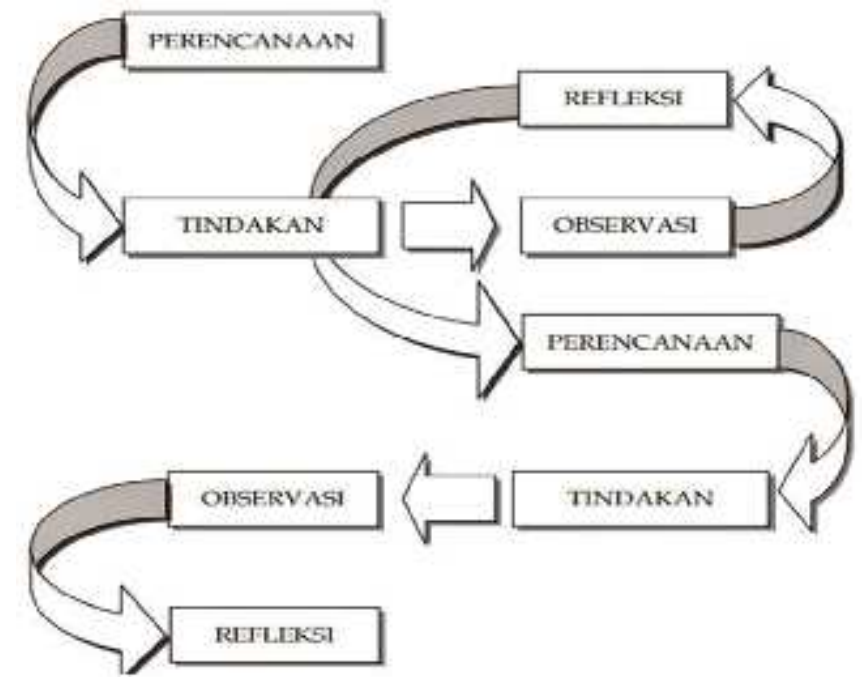

Gambar 1. Tahapan dalam siklus Penelitian Tindakan Kelas Model Kemmis \& Taggart.

Sumber: Arikunto,2012:20.

Pada dasarnya desain penelitian ini merupakan penelitian Tindakan Kelas (PTK). Menurut Kemenddikbud (2015:6) dalam buku penelitian tindakan kelas, "penelitian tindakan kelas adalah penelitian tindakan yang dilakukan oleh guru dengan tujuan memperbaiki mutu praktik pembelajaran di kelasnya. Penelitian ini merupakan jenis penelitian tindakan kelas secara kolaboratif dan parsitipatif. Artinya peneliti tidak melakukan sendiri, namun berkolaborasi dengan guru kelas. Secara partisipatif bersama-sama dengan mitra peneliti akan melaksanakan penelitian ini langkah demi langkah. Sedangkan pendekatan yang digunakan dalam penelitian ini adalah pendekatan kualitatif, yaitu prosedur penelitian yang menghasilkan data deskriptif berupa kata-kata tertulis. Data-data yang diperoleh dari penelitian baik melalui pengamatan, tes atau dengan menggunakan metode yang lain kemudian diolah dengan analisis deskriptif untuk menggambarkan keadaan peningkatan pencapaian indikator keberhasilan tiap siklus dan untuk menggambarkan peningkatan hasil peserta didik di kelas 9A SMP Negeri 17 Jakarta setelah menggunakan model pembelajaran discovery learning. 
Adapun teknik pengumpulan data yang berbentuk kuantitatif berupa data-data yang disajikan berdasarkan angka-angka, maka analisis yang digunakan adalah prosentase. Subyek yang dijadikan penelitian adalah siswa kelas 9A SMPN 17 Jakarta tahun pelajaran 2019/2020 yang berjumlah 35 siswa, karena dipandang perlu meningkatkan hasil belajarnya khususnya materi pemahaman membaca teks report. Lokasi penelitian bertempat di SMPN 17 Jakarta dengan jumlah siswa seluruhnya berjumlah 35 siswa. Pembelajaran dilaksanakan mulai 8 Februari 2019 sampai dean tanggal 2 April 2019. Penelitian ini dilakukan dengan tindakan yang dilaksanakan dengan langkah-langkah penelitian yang telah direncanakan, yaitu dengan terlebih dahulu menyusun RPP yang berisi langkah-langkah dalam pelaksanaan pembelajaran. Langkah selanjutnya adalah berupaka pengumpulan data yang dilalksanakan dengan melakukan observasi, pre test maupun post test. Setelah data diperoleh kemudian dilakukan refleksi dan melakukan laporan hasil penelitian. Tindakan siklus I pertemuan pertama dilaksanakan pada hari Jumat, 8 Maret 2019 dan pertemuan kedua pada Jumat, 15 Maret 2019. Sedangkan tindakan siklus II pertemuan pertama dilaksanakan pada 22 Maret 2019 dan pertemuan kedua pada Jumat, 2 April 2019.

Data yang diperoleh dari penelitian ini berupa data awal yang didapatkan dari data pre tindakan, data yang diperoleh pada saat tindakan dan data hasil tindakan. Peneliti memperoleh data awal tindakan dari hasil observasi di kelas sebelum ada tindakan. Dari data awal didapatkan informasi bahwa peserta didik memerlukan tindakan untuk memecahkan permasalahan rendahnya kemampuan pemahaman materi reading comprehension. Data inti diperoleh selama tindakan. Dari hasil tindakan diperoleh data verbal yaitu data yang diperoleh peneliti selama observasi. Dalam data ini peneliti mencatat aktifitas peserta didik dan juga aktifitas yang dilakukan guru selama tindakan berlangsung. Data ini selanjutnya dikategorikan data aktifitas peserta didik dan data aktifitas guru. Selain data verbal, peneliti memproleh data non verbal yang didapatkan dari hasil post test sesudah tindakan siklus I dan siklus II. Dari tampilan data baik verbal maupun non verbal, peneliti memperoleh hasil refleksi yang didukung oleh guru dan teman sejawat yaitu berupa kelemahankelemahan serta hambatan yang ditemukan yang selanjutkan dipakai sebagai dasar perbaikan pada siklus berikutnya.

\section{HASIL DAN PEMBAHASAN}

Sebelum melaksanakan siklus I, peneliti melakukan survei awal untuk mengetahui kondisi yang ada di lapangan. Dari kegiatan survei ini, peneliti menemukan bahwa kualitas proses dan hasil pembelajaran membaca pemahaman teks report di kelas 9A SMP Negeri 17 Jakarta semester genap tahun 2019/2020, masih tergolong rendah. Kemudian, peneliti melakukan penelitian untuk mengatasi masalah tersebut dengan menerapkan model pembelajaran discovery Learning. Kemudian, 
peneliti menyusun rencana untuk siklus I. Siklus pertama ini mendeskripsikan pembelajaran membaca pemahaman teks report dengan menerapkan model discovery Learning kekurangan dalam pelaksanaannya.

Sebelum dilaksanakan penelitian untuk mengetahui kemampuan siswa membaca pemahaman teks report, guru menggunakan data hasil ulangan harian untuk mengetahui kemampuan awal siswa dalam membaca pemahaman teks report. Adapun hasil nilai tes/ulangan pada pra tindakan diperoleh data sebagai berikut:

Tabel 1. Hasil Belajar Membaca Pemahaman Teks Report Pra Siklus

\begin{tabular}{|l|l|}
\hline Nilai Rata-rata & 73,94 \\
\hline Jumlah siswa yang tuntas & 17 \\
\hline Jumlah siswa yang tidak tuntas & 18 \\
\hline Prosentase ketuntasan belajar & $48,6 \%$ \\
\hline Nilai tertinggi & 94 \\
\hline Nilai terendah & 60 \\
\hline Tingkat keaktifan siswa & $45,7 \%$ \\
\hline
\end{tabular}

Dari tabel di atas, dapat diketahui kemampuan awal siswa dalam membaca pemahaman teks report dengan nilai rata-rata 73,94, nilai terendah 60 , nilai tertinggi 94 dengan jumlah siswa tuntas sebanyak 17 siswa atau 48,6\% dan jumlah siswa yang tidak tuntas 18 atau $51,4 \%$. Tingkat keaktifan siswa dalam proses pembelajaran sebanyak $45,7 \%$. Dari hasil pengamatan dan paparan hasil di atas dapat diambil kesimpulan:

a. Keaktifan siswa dalam mengikuti pembelajaran: 45,7\% atau hanya 16 siswa yang aktif dalam kegiatan belajar

b. Nilai rata-rata kemampuan siswa membaca pemahaman teks report pada pra siklus sebesar 73,94 dengan ketuntasan klasikal sebesar 48,6\%.

Teknik pengumpulan data yang digunakan dalam penelitian tindakan kelas ini adalah sebagai berikut :

1. Teknik Tes

2. Metode Observasi

Teknik Analisis Data

1. Data aktivitas peserta didik

Tabel 1. Kriteria Penilaian Observasi Aktivitas Belajar Siswa

\begin{tabular}{llll}
\hline No & Skor & Kriteria & Keterangan \\
\hline $\mathbf{1}$ & 1 & Indikator tidak muncul & \\
$\mathbf{2}$ & 2 & Indikator muncul, tidak aktif & \\
$\mathbf{3}$ & 3 & Indikator muncul, kurang aktif & \\
$\mathbf{4}$ & 4 & Indikator muncul, aktif & \\
\hline
\end{tabular}


Tabel 2. Penilaian Hasil Observasi Aktivitas Belajar Siswa

\begin{tabular}{llll}
\hline No & Rentang Nilai & Kriteria Nilai & Keterangan \\
\hline $\mathbf{1}$ & $>=90$ & Baik Sekali & - \\
$\mathbf{2}$ & $70-89$ & Baik & Tuntas \\
$\mathbf{3}$ & $50-69$ & Cukup & Blm Tuntas \\
$\mathbf{4}$ & $<50$ & Kurang & Blm Tuntas \\
\hline \multicolumn{2}{r}{ Persentase $(\%)=\frac{2}{\text { Jumlah Peserta Didik }} \times 100 \%$} &
\end{tabular}

2. Data mengenai hasil belajar

Untuk menghitung nilai rata-rata digunakan rumus:

$$
\bar{x}=\frac{\sum x}{n}
$$

Keterangan:

$\mathrm{x}=$ rata-rata nilai

$\Sigma^{\mathrm{x}} \quad=\quad$ jumlah seluruh nilai

$\mathrm{N}=$ jumlah peserta didik

b) Menghitung ketuntasan klasikal

$$
\frac{\sum \text { Peserta Didik Tuntas Belajar }}{\sum \text { Seluruh Peserta Didik }}
$$

3. Indikator Keberhasilan

Kriteria keberhasilan proses perbaikan pembelajaran dalam penelitian ini dapat ditetapkan sebagai berikut :

1. Siswa dinyatakan tuntas jika telah mencapai tingkat penguasaan materi $85 \%$ ke atas atau mendapat nilai 75.

2. Proses perbaikan pembelajaran dinyatakan berhasil jika minimal $85 \%$ dari jumlah siswa tuntas dalam belajar.

3. Pelaksanaan perbaikan pembelajaran dinyatakan berhasil apabila peningkatan aktivitas belajar siswa mencapai $85 \%$ atau lebih dari jumlah seluruh siswa

\section{HASIL PENELITIAN DAN PEMBAHASAN}

\section{Deskripsi Pra Siklus}

Sebelum dilaksanakan penelitian untuk mengetahui kemampuan siswa membaca pemahaman teks report, guru menggunakan data hasil ulangan harian untuk mengetahui kemampuan awal siswa dalam membaca pemahaman teks report. Adapun hasil nilai tes/ulangan pada pra tindakan diperoleh data sebagai berikut: 
Tabel 3. Hasil Belajar Membaca Pemahaman Teks Report Pra Siklus

\begin{tabular}{|l|l|}
\hline Nilai Rata-rata & 73,94 \\
\hline Jumlah siswa yang tuntas & 17 \\
\hline Jumlah siswa yang tidak tuntas & 18 \\
\hline Prosentase ketuntasan belajar & $48,6 \%$ \\
\hline Nilai tertinggi & 94 \\
\hline Nilai terendah & 60 \\
\hline Tingkat keaktifan siswa & $45,7 \%$ \\
\hline
\end{tabular}

Dari tabel di atas, dapat diketahui kemampuan awal siswa dalam membaca pemahaman teks report dengan nilai rata-rata 73,94, nilai terendah 60, nilai tertinggi 94 dengan jumlah siswa tuntas sebanyak 17 siswa atau 48,6\% dan jumlah siswa yang tidak tuntas 18 atau 51,4\%. Tingkat keaktifan siswa dalam proses pembelajaran sebanyak $45,7 \%$.

\section{Deskripsi Siklus 1}

a. Tahap persiapan, meliputi:

1) Menyusun perangkat pembelajaran, menyiapkan media pembelajaran, menyiapkan rubrik penilaian unjuk kerja. Kemudian, peneliti menyusun pedoman observasi untuk mengamati keaktifan, kerja sama dan sikap siswa selama kegiatan pembelajaran berlangsung.

2) Merencanakan skenario pembelajaran membaca pemahaman teks report dengan model discovery Learning, yang nantinya akan dilaksanakan pada siklus 1 .

b. Tahap Pelaksanaan

Pertemuan 1

1) Guru memberikan apersepsi

2) Guru menyampaikan KD dan tujuan pembelajaran.

3) Guru mengelompokkan siswa satu kelompok empat orang dengan mempertimbangkan aspek perbedaan hasil belajar membaca pemahaman teks report.

4) Guru menerangkan tentang text information report.

5) Guru memberi tugas kepada masing-masing kelompok untuk mengumpulkan informasi dari materi teks information report

6) Siswa berdiskusi secara berkelompok yaitu mengolah informasi dari materi teks information report yang sudah dikumpulkan dari hasil kegiatan/pertemuan sebelumnya mau pun hasil dari kegiatan mengamati dan kegiatan mengumpulkan informasi yang sedang berlangsung dengan bantuan pertanyaan-pertanyaan pada lembar kerja..

7) Guru menugasi masing-masing kelompok tersebut untuk maju menuliskan dan mempresentasikan hasil diskusi mereka. 
8) Siswa mengemukakan pendapat atas presentasi yang dilakukan tentanag materi Teks Information Report dan ditanggapi oleh kelompok yang mempresentasikan

9) Guru bersama sama dengan siswa merangkum hasil diskusi mereka

10) Memberikan penghargaan untuk materi pelajaran Teks Information Report kepada kelompok yang memiliki kinerja dan kerjasama yang baik.

\section{Pertemuan 2}

1) Peserta didik diberi motivasi atau rangsangan untuk memusatkan perhatian pada topik materi Kalimat deklaratif dalam simple present tense dan passive voice (konteks teks information report)

2) Guru memberikan kesempatan pada peserta didik untuk mengidentifikasi sebanyak mungkin pertanyaan yang berkaitan dengan gambar yang disajikan dan akan dijawab melalui kegiatan belajar.

3) Mengolah informasi dari materi Kalimat deklaratif dalam simple present tense dan passive voice (konteks Teks Information Report ) yang sudah dikumpulkan dari hasil kegiatan/pertemuan sebelumnya mau pun hasil dari kegiatan mengamati dan kegiatan mengumpulkan informasi yang sedang berlangsung dengan bantuan pertanyaan-pertanyaan pada lembar kerja.

4) Siswa berdiskusi secara berkelompok yaitu mengolah informasi dari materi Kalimat deklaratif dalam simple present tense dan passive voice (konteks Teks Information Report ) yang sudah dikumpulkan dari hasil kegiatan/pertemuan sebelumnya mau pun hasil dari kegiatan mengamati dan kegiatan mengumpulkan informasi yang sedang berlangsung dengan bantuan pertanyaan-pertanyaan pada lembar kerja.

5) Guru menugasi masing-masing kelompok tersebut untuk maju menuliskan dan mempresentasikan hasil diskusi mereka.

6) Siswa mengemukakan pendapat atas presentasi yang dilakukan tentanag materi Kalimat deklaratif dalam simple present tense dan passive voice (konteks Teks Information Report) dan ditanggapi oleh kelompok yang mempresentasikan

7) Guru bersama sama dengan siswa merangkum hasil diskusi mereka

8) Tes Siklus I

Penilaian membaca pemahaman teks report dengan hasil sebagai berikut.

Tabel 4. Hasil Belajar Membaca Pemahaman Teks Report Siklus I

\begin{tabular}{|l|l|}
\hline Nilai Rata-rata & 77,29 \\
\hline Jumlah siswa yang tuntas & 25 \\
\hline Jumlah siswa yang tidak tuntas & 10 \\
\hline Persentase ketuntasan belajar & $71,4 \%$ \\
\hline Nilai tertinggi & 90 \\
\hline Nilai terendah & 65 \\
\hline Persentase Tingkat keaktifan siswa & $65,7 \%$ \\
\hline
\end{tabular}


Dari tabel di atas, dapat diketahui keterampilan membaca pemahaman teks report pada siklus I diperoleh nilai rata-rata 77,29, nilai terendah 65 , nilai tertinggi 90 dengan jumlah siswa tuntas sebanyak 25 siswa atau 71,4\% dan jumlah siswa yang tidak tuntas 10 atau $28,6 \%$. Tingkat keaktifan siswa dalam proses pembelajaran sebanyak $65,7 \%$.

\section{c. Refleksi Siklus 1}

Berdasarkan hasil observasi tersebut, dilakukan analisis dan refleksi sebagai berikut.

1) Guru menjadi fasilitator dalam pengajaran, sehingga proses pembelajaran tidak berpusat pada guru, siswa terlibat lebih aktif

2) Hasil belajar membaca pemahaman teks report naik dari penilaian sebelum tindakan. Setelah dilakukan analisis pada hasil jawaban siswa, di dapat satu kesimpulan siswa 28,6\% belum memahami pola kalimat deklaratif dalam simple present tense dan passive voice (konteks Teks Information Report). Untuk itu perlu dilaksanakan siklus II.

\section{Deskripsi Siklus II}

\section{a. Pelaksanaan}

\section{Pertemuan 1}

1) Peserta didik diberi motivasi atau rangsangan untuk memusatkan perhatian pada topik materi Kalimat interogatif dalam simple present tense dan passive voice (konteks Teks Information Report)

2) Guru memberikan kesempatan pada peserta didik untuk mengidentifikasi sebanyak mungkin pertanyaan yang berkaitan dengan gambar yang disajikan dan akan dijawab melalui kegiatan belajar, contohnya mengajukan pertanyaan tentang materi : kalimat interogatif dalam simple present tense dan passive voice (konteks Teks Information Report).

3) Peserta didik dan guru secara bersama-sama membahas contoh dalam buku paket mengenai materi Kalimat interogatif dalam simple present tense dan passive voice (konteks Teks Information Report)

4) Menyampaikan hasil diskusi tentang materi Kalimat interogatif dalam simple present tense dan passive voice (konteks Teks Information Report ) berupa kesimpulan berdasarkan hasil analisis secara lisan, tertulis, atau media lainnya untuk mengembangkan sikap jujur, teliti, toleransi, kemampuan berpikir sistematis, mengungkapkan pendapat dengan sopan.

5) Mempresentasikan hasil diskusi kelompok secara klasikal:

6) Siswa bertanya tentang hal yang belum dipahami, atau guru melemparkan beberapa pertanyaan kepada siswa berkaitan dengan materi Kalimat interogatif dalam simple present tense dan passive voice (konteks Teks Information Report ) yang akan selesai dipelajari

\section{Pertemuan 2}

1) Peserta didik diberi motivasi atau rangsangan untuk memusatkan perhatian pada topik materi Nomina singular dan plural dengan atau tanpa a, the, this, those, my, their, dsb (konteks Teks Information Report) 
2) Guru memberikan kesempatan pada peserta didik untuk mengidentifikasi sebanyak mungkin pertanyaan yang berkaitan dengan gambar yang disajikan dan akan dijawab melalui kegiatan belajar, contohnya mengajukan pertanyaan tentang materi : Nomina singular dan plural dengan atau tanpa a, the, this, those, my, their, dsb (konteks Teks Information Report).

3) Peserta didik dan guru secara bersama-sama membahas contoh dalam buku paket mengenai materi Nomina singular dan plural dengan atau tanpa a, the, this, those, my, their, dsb (konteks Teks Information Report).

4) Menyampaikan hasil diskusi tentang materi Nomina singular dan plural dengan atau tanpa $a$, the, this, those, my, their, dsb (konteks Teks Information Report).berupa kesimpulan berdasarkan hasil analisis secara lisan, tertulis, atau media lainnya untuk mengembangkan sikap jujur, teliti, toleransi, kemampuan berpikir sistematis, mengungkapkan pendapat dengan sopan.

5) Mempresentasikan hasil diskusi kelompok secara klasikal:

6) Selanjutnya dilaksanakan tes siklu II dengan hasil sebabagai berikut.

Tabel 5. Hasil Belajar Membaca Pemahaman Teks Report Siklus II

\begin{tabular}{|l|l|}
\hline Nilai Rata-rata & 83,71 \\
\hline Jumlah siswa yang tuntas & 32 \\
\hline Jumlah siswa yang tidak tuntas & 3 \\
\hline Persentase ketuntasan belajar & $91,4 \%$ \\
\hline Nilai tertinggi & 95 \\
\hline Nilai terendah & 70 \\
\hline Persentase Tingkat keaktifan siswa & $94,3 \%$ \\
\hline
\end{tabular}

Dari hasil analisis yang dilukiskan dalam bentuk tabel di atas diketahui hasil belajar membaca pemahaman teks report pada siklus II diperoleh nilai rata-rata 83,71, nilai terendah 70, nilai tertinggi 95 dengan jumlah siswa tuntas sebanyak 32 siswa atau 91,4\% dan jumlah siswa yang tidak tuntas 3 siswa atau 8,6\%. Tingkat keaktifan siswa dalam proses pembelajaran sebanyak $94,3 \%$. Dengan demikian, siklus II ini tuntas secara klasikal di atas $85 \%$. Oleh karena itu penelitian ini selesai pada siklus II, tidak dilanjutkan siklus III. 


\section{PEMBAHASAN}

\section{Peningkatan Aktivitas Belajar Siswa}

Peningkatan perubahan tingkah laku belajar dapat dilihat dalam tabel di bawah ini.

Tabel 6. Peningkatan Aktivitas Belajar Siswa

\begin{tabular}{|l|l|l|l|}
\hline Aktivitas Belajar & Pra Siklus & Siklus I & Siklus II \\
\hline Aktif & 16 siswa & 23 siswa & 33 siswa \\
\hline Tidak Aktif & 19 siswa & 12 siswa & 2 siswa \\
\hline
\end{tabular}

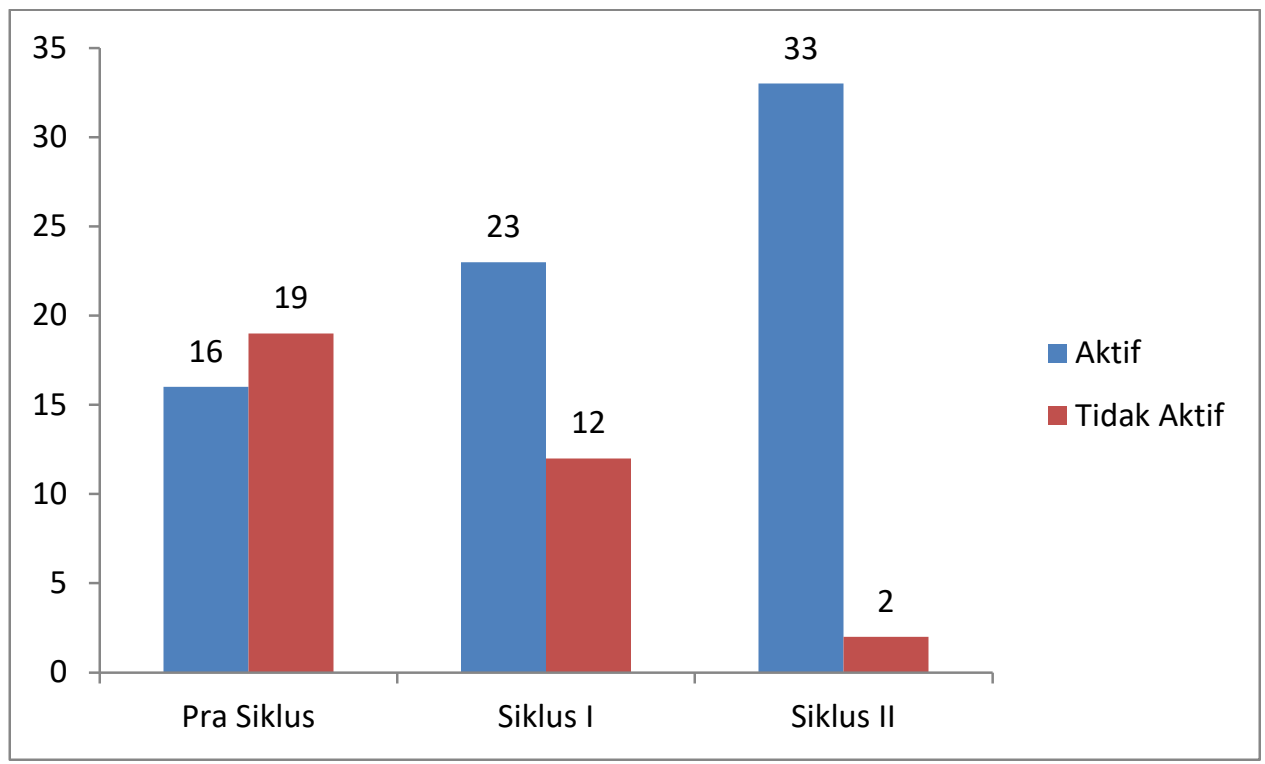

Gambar 2. Histogram Peningkatan Aktivitas Belajar Siswa

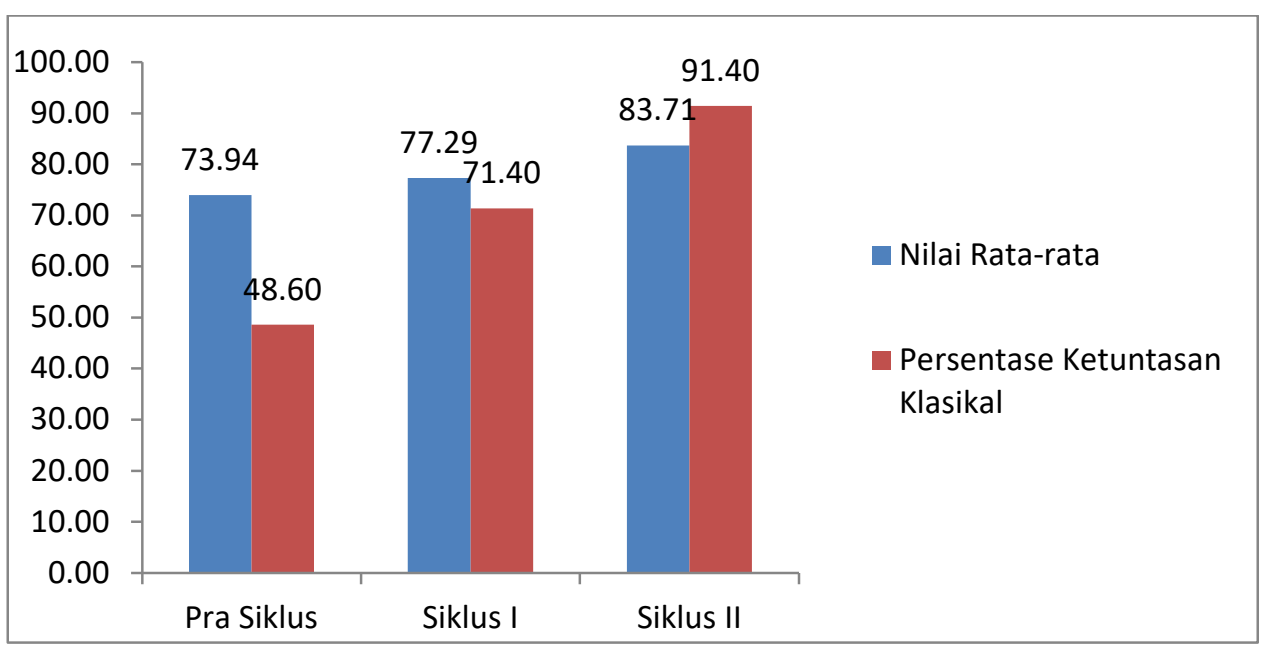

Gambar 3. Peningkatan Hasil Belajar Membaca Pemahaman Teks Report

Siklus 2 dilaksanakan untuk mengatasi kelemahan atau kekurangan yang ada pada siklus 1. Model discovery Learning juga sebagai sarana bagi guru untuk 
memotivasi siswa agar lebih aktif dalam kegiatan pembelajaran. Peningkatan hasil belajar membaca pemahaman teks report dengan model discovery Learning sangat cocok dan berpengaruh langsung terhadap perolehan nilai siswa, dari pra siklus, tindakan siklus 1 sampai tindakan siklus 2. Hasil belajar membaca pemahaman teks report sangat terlihat perkembangannya. Dengan demikian terjadi peningkatan aktivitas belajar dan hasil belajar membaca pemahaman teks report setelah diberikan model pembelajaran discovery learning pada siswa kelas 9A SMP Negeri 17 Jakarta pada semester genap tahun pelajaran 2019/2020.

Peningkatan hasil belajar membaca pemahaman teks report dengan model discovery Learning sangat cocok dan berpengaruh langsung terhadap perolehan nilai siswa, dari pra siklus, tindakan siklus 1 sampai tindakan siklus 2. Hasil belajar membaca pemahaman teks report sangat terlihat perkembangannya. Hasil penelitian ini sesuai dengan penelitian yang dilakukan Suprihatiningrum. (2013) yang menyatakan adanya pengaruh minat baca dan hasil belajar membaca dengan menggunakan metode discovery Learning dibandingkan dengan metode belajar konvensional. Penerapan model discovery Learning dapat meningkatkan minat baca dan hasil belajar.

\section{KESIMPULAN}

Berdasarkan penelitian ini dapat disimpulkan bahwa:

1. Penerapan model pembelajaran discovery learning ternyata mampu meningkatkan hasil belajar membaca pemahaman teks report. Hal ini dapat diketahui dari adanya peningkatan jumlah siswa yang mengalami ketuntasan belajar dari siklus 1 hingga siklus II. Hal ini dapat dibuktikan dengan hasil belajar membaca pemahaman teks report menggunakan model discovery Learning. Nilai rata-rata hasil belajar membaca pemahaman teks report pada pra siklus adalah 73,94 meningkat menjadi 77,29 pada siklus I dan 83,71 pada siklus II. Jumlah siswa tuntas pada pra siklus ada $48,6 \%$, meningkat menjadi $71,4 \%$ pada siklus I dan meningkat lagi sebesar 91,4\% pada siklus II.

2. Telah terjadi perubahan perilaku aktivitas belajar yang signifikan pada siswa. Hal ini ditunjukkan dengan adanya peningkatan keaktifan siswa pada siklus 1 siswa yang aktif 65,7\%, pada siklus II terjadi peningkatan, yakni mencapai 94,3\%.

3. Telah terjadi perubahan perilaku aktivitas belajar yang signifikan pada siswa. Hal ini ditunjukkan dengan adanya peningkatan keaktifan siswa pada siklus 1 siswa yang aktif $65,7 \%$, pada siklus II terjadi peningkatan, yakni mencapai 94,3\%.

Saran yang dapat disampaikan yaitu: (1) Siswa diharapkan dapat bekerja sama selama kegiatan memecahkan masalah dan menemukan sendiri jawabannya. (2) Guru hendaknya mengubah pembelajaran membaca pemahaman teks report dari guru sentris atau teacher-centered menjadi siswa sentris student-centered dengan menerapkan model discovery Learning. (3) Hendaknya sekolah menyediakan fasilitas yang cukup untuk pengembangan pembelajaran yang bevariasi dan inovatif (4) Penelitian ini hanya terbatas pada mata pelajaran Bahasa Inggris dan hasil belajar 
ranah pengetahuan serta minat baca, sebaiknya peneliti lain dapat melanjutkan penelitian ini pada obyek lain.

\section{DAFTAR PUSTAKA}

Arikunto, Suharsimi. (2012). Penelitian Tindakan Kelas. Jakarta : Bumi Aksara

Badan Pusat Kurikulum Dinas Pendidikan Dasar (2006) Kurikulum Tingkat Satuan Pendidikan. Jakarta: Disdik

Budiningsih, Asri. (2005). Belajar dan Pembelajaran. Jakarta : Rineka Cipta

Burns, dkk (2005). Membaca Sebagai Proses Pembelajaran. Bandung: Sinar Baru

COED (2001) Concise Oxford English Dictionary, 10 th edition, Oxford University. Press

Hamdani. (2011) Strategi Belajar Mengajar. Bandung: CV. Pustaka

Hanafiah, dan Cucu Suhana. (2009). Konsep Strategi Pembelajaran. Bandung: PT. Refika aditama

Iskandarwassid; Dadang Sunendar. (2013). Strategi Pembelajaran Bahasa. Bandung: PT Remaja Rosdakarya

Margono. (2000). Metodologi Penelitian Pendidikan. Jakarta: Rineka Cipta.

Mulyono. (2012). Strategi Pembelajaran Menuju Efektifitas Pembelajaran di Abad Global. UIN-Maliki Press

Nanda Widya, dalam https://www.studiobelajar.com/report-text/diakses tanggal 1 Oktober 2020).

Nurhadi, (2004). Bagaimana meningkatkan kemampuan membaca? . Bandung: Sinar. Baru

Priyatni, Endah T. (2014). Desain pembelajaran bahasa indonesia dalam kurikulum. 2013. Jakarta: Bumi Aksara

Soedarso. (2010). Speed Reading: Sistem Membaca Cepat dan Efektif. Jakarta: Gramedia

Sudrajat. (2001). Pengertian-pendekatan-strategi-metode-teknik-taktik-dan-modelpembelajaran. http://akhmadsudrajat.wordpress.com.2008/09/12. Diakses tanggal 13 Februari 2019.

Suprihatiningrum. (2013). Strategi Pembelajaran Teori dan Aplikasinya. Yogyakarta: Ar-Russ Media.

Zuchdi. (2008). Kemampuan Membaca, Teknik Membaca Efektif dan. Efisien. Bandung: Angkasa. 